\title{
Editorial
}

1981 in Britain will be remembered as the year when there were three million unemployed, when Irish prisoners died on hunger strike, when there were riots in almost all major city centres - and when the British public was entertained by two full scale spectacles: the trial of Peter Sutcliffe, the 'Yorkshire Ripper' and the Royal Wedding of Prince Charles and Lady Diana Spencer. In both cases a legal procedure, a trial and a marriage, have provided a form in which sexual order and dynastic and political continuity may be ensured.

In this issue of Feminist Review we publish an analysis of the Sutcliffe trial by Wendy Hollway in which she criticizes the way in which the event was constructed by the media and the way in which it was presented juridically. Despite the thousands of words that have been written about the trial, there is still no account outside the 'left' or alternative press that seeks to expose the presumptions about the nature of male and female sexuality which were assumed in the trial and in the commentaries upon it. Ironically, the media did give some space to feminists who were mobilizing around the issues of male violence and the 'Ripper' case before Peter Sutcliffe was actually arrested, but women's anger was incorporated into conventional 'law and order' positions which interpreted the 'Ripper's' behaviour as both 'sick' and 'evil' - as deserving the heaviest punishment - while glossing over its continuity with 'normal' male behaviour towards women in our society. The implications of these events as well as further analysis of sexual violence are, we feel, important issues for socialist feminists and we would welcome further contributions on this subject.

In a different context, many of the issues concerning the construction of female sexuality are dealt with in the article by Celia Cowie and Sue Lees ( to be followed in a later issue by an article by Mica Nava on young women and lesbianism). This article deals with the experience of young women, their perceptions of their sexuality and the forces that control and determine it.

The article by Julia Brophy and Carol Smart is the first we have published to deal with family law and legal processes. The authors argue that modern developments in family law have not been to the advantage of women (as is often argued) but rather serve to confirm their position as mothers and as financial dependants of men. Far from giving women independent rights, the liberalization of family law has recreated an ideology in which relations of domination and submission are incorporated in the roles of husband/father and mother/wife. 


\section{Feminist Review}

The significance of the family in determining women's relationship to the forces of production is an issue taken up by two articles which at first glance may seem far apart. Cynthia Cockburn looks at the development of the sexual division of labour in the printing industry and puts forward an account of how women have been excluded from the more skilled and better paid work in printing. This is often explained in terms of what goes on in the family, and how this affects women at work, but Cynthia Cockburn argues that we should pay more attention to male power in the workplace; and in particular how jobs are created around greater male physical strength and the way men have appropriated knowledge and control of machinery.

Haleh Afshar makes a rather different case. Her article - our second on Iran - is based on a study of an Iranian village and the effect of the introduction of commodity production, carpet weaving, on the women's relationship to the men in the village. Her argument is that it is precisely men's dominance within the family that allows them to appropriate income generated by women's work, and therefore the labour of their wives. The result, she argues, is that women's entry into production has not emancipated them, but that, although they become more and more crucial to the production process, men nevertheless control the income from the women's labour, even if they do not control the means of production. This is a detailed case study of a general point made by Diane Elson and Ruth Pearson in their article in issue number 7 of Feminist Review.

Janine Morgall provides an account of the nature and effect of the new office technology, in particular of the introduction of word processing equipment. She shares many of the concerns expressed by Cynthia Cockburn - the consequences of deskilling,the ways in which exploitation of the new technology, may, not only strengthen managerial control over workers and the labour process, but reinforce the division between 'men's' and 'women's' work. However, Janine Morgall goes on to detail the kinds of political response which women need to make in order that they may benefit rather than be further oppressed by office technology.

We are also publishing in this issue an article by Toril Moi on Freud's case study of 'Dora' - a text of considerable interest to contemporary feminists. This is our second article in successive issues of Feminist Review to take a critical stance towards the use of psychoanalysis by feminists. However, we wish to make it clear that the appearance of the two articles is fortuitous in that it does not represent a 'Feminist Review position'. Indeed we would welcome a defence or development of the use of psychoanalysis by feminists and in feminist theory, whether cast in the form of replies to the articles by Toril Moi and Elizabeth Wilson or as independent contributions.

We also include in this issue a reply to the article by Jane Humphries in Feminist Review number 7 , which dealt with the mining industry in nineteenth century Britain and protective legislation, and we welcome all such responses to articles we have published. This may be one way in which we as a journal can come to grips with some of the issues raised by Anna Frankel in her letter, which we also publish. That is, we believe that it is possible to publish a journal which does treat issues at some length whilst also being alive to the contentious issues involved and the consequences of these debates for political practice. We hope that with more varied contributions and responses we can be politically engaged as well as providing space for argument and reflection.

Anna Frankel also raises the issue of men writing for Feminist Review. We made a decision that only women's work would be published and we have always seen Feminist Review as part of the political project of the women's liberation movement. In addition we felt that there were a number of other outlets for male writers who write on issues of concern for women. We still regard this decision as correct, although - as with other decisions - it will be reviewed and discussed again. 